\title{
what is a literary intellectual? Creative Writing and the New Humanities \\ PAUL DAWSON
}

I would like to discuss how the emergent area of Creative Writing in Australian universities might be situated in relation to what have become known as the New Humanities. ${ }^{1}$ The first question to ask is what are the New Humanities? The term was first used by Ian Donaldson at a symposium for the Australian Academy of the Humanities in 1989. Donaldson pointed out that in the previous few decades new modes of theoretical and methodological inquiry had contributed to a breakdown of the traditional divide between the humanities and the social sciences, between a refined liberal humanist world of the arts and a more rigorous analysis of society. The New Humanities, as he describes the work of research centres in America, are concerned with 'reconfiguring knowledge ... bringing together new combinations of scholarly and theoretical enquiry' and 'redrawing old taxonomies within the academy'.2

What Donaldson is referring to here are the disciplinary, curricular and policy changes wrought within the academy by the impact of what we know as Theory. His tentative phrase was solidified into an institutionally accredited term when the Academy's symposium of 1991 was entitled Beyond the Disciplines: The New Humanities. In the introduction to these proceedings Ken Ruthven writes that those 'who are making the running in the new humanities' use critical theory as a 'heuristic device' for identifying occluded knowledges. ${ }^{3}$ The papers published, by critics such as John Frow, Meaghan Morris and Tony Bennett, were all concerned with the new interdisciplinary enterprise of Cultural Studies. And indeed, in 1996, Cultural and Communication Studies was included as the tenth electoral section of the Academy, thus becoming the exemplary discipline of the New Humanities. As Jonathan Culler has claimed, in an almost too neat formulation, Cultural Studies is Theory put into practice. ${ }^{4}$ 
Before discussing how the discipline of Creative Writing relates to this post-Theory academy, it is worth asking what value is assigned to literature or 'creative writing' in the New Humanities. In 1999 the academic journal Southern Review changed its 25-year-old subtitle, 'Literary and Interdisciplinary Essays' to 'Essays in the New Humanities'. As Cathy Greenfield explains in her editorial, the word 'literary' was dropped because this was no longer the journal's primary focus. Rather than privileging literature as an aesthetic category, the journal is interested in its function as a discourse alongside other cultural practices and forms of media. It is worth noting here the 'aims and scope' of the journal. According to these aims Southern Review 'publishes essays, articles, reviews and review articles on a wide range of cultural and media matters, as well as fiction and poetry'. The journal goes on to explain that it seeks essays of an interdisciplinary nature concerned not only with texts, but also with the wider discursive relations in which they are implicated. There are no prescriptions for fiction or poetry. Is this out of deference, I wonder, to the writer's donnée, a retention of aesthetic criteria in the publication of literature that are being rejected as concerns for literary criticism? Why does a journal concerned with essays in the New Humanities publish fiction and poetry? And what sort of writing would be appropriate?

The UTS Review, which was subtitled 'Cultural Studies and New Writing', claimed to offer 'an international space for academic and creative writing on culture', but 'creative writing that no longer construes "the literary" as a site of withdrawal from politics, from the worlds created by the media and other technologies, from new practices of history and from the social sciences'. 5 This editorial policy is more theoretically consistent, although since the journal's inception in 1995 only a handful of pieces have been published under the category of 'new writing'. Many of the 'articles' published, however, could be classified as fictocriticism, creative non-fiction, or confessional criticism. What this indicates is that there is a certain type of writing suitable to the journal's aims. The appellation 'new' refers to a currency not only in terms of temporality but also in terms of formal innovation or experimentation, especially with generic boundaries. This suggests the possibility of an avant-garde 'writing' (as opposed to 'literature') which could be aligned with the academic work of the New Humanities.

What position does the discipline of Creative Writing, which concerns itself with the production of literary works, occupy in the New Humanities? Creative Writing is not necessarily founded on a concept of the literary as a site of withdrawal from politics and society, but neither is the main function of the writing workshop to interrogate the theoretical and cultural status of literature: it is to establish a standard of literary value by which to identify what 'works' in exemplary texts and to apply these principles to the aesthetic improvement of student manuscripts. Furthermore, while in Australia Creative 
Writing has followed the same trajectory as the New Humanities, emerging through newer institutions in the wake of challenges to traditional forms of knowledge, its historical and theoretical ties remain with the American New Criticism, which construed the literary precisely in terms of aesthetic autonomy. ${ }^{6}$ I shall return to this later.

Creative Writing is also generally regarded as an apprenticeship for aspiring writers. That is, it provides skills training for those who wish to enter the 'literary establishment' via mainstream publication. This is why writing programmes advertise the number of 'successful' graduates who have published their work. By the term 'literary establishment' I mean reviewers, editors, publishers and writers whose domain of professional work involves the production and reception of literature, and who conceptualise this domain as the 'public sphere' because it is located largely outside the academy. The response of this literary establishment to the 'culture wars', bemoaning the professional jargon of academics and the relativisation of literary value perpetrated by postmodernism, establishes its opposition to critical theory. David Williamson's highly successful play Dead White Males (1995) is a locus classicus for this response.

What is at stake in this debate between writers and the academy is less an understanding of literature than a struggle over who wields literary authority. If the discipline of Creative Writing is to assume a non-antagonistic institutional position within the New Humanities, I feel it is less important to engage in theoretical debates about what constitutes literature than to ask: what is a literary intellectual? That is, around what figure in the academy has literary authority traditionally accrued, and how can a vision of authorship be elaborated in relation to it? This figure has been the critic.

\section{- Practical criticism}

Modern academic criticism can trace its origins to the work of Matthew Arnold, for whom the function of criticism was to contribute to the role of culture in maintaining social stability by establishing the critical base for a continuum of literary works from age to age. ${ }^{7}$ This cultural mission was joined with the traditional role of evaluating literature in the professional practice and pedagogical tool known as practical criticism. The technique for this academic movement comes from I.A. Richards's experiments with unattributed poems on student readers, and its theory from T.S. Eliot's modernist notions of impersonality in art, and it held sway over Anglo-American criticism and education for the first part of the twentieth century due to the influence of F.R. Leavis and the American New Critics, before spreading throughout the Commonwealth, including Australia. 8

The figure of literary authority that Practical Criticism promoted within the academy was one of the critic as the moral guardian of our cultural heritage, finding in literature a 
spiritual balm in the face of science and mass civilisation. This figure in fact appropriated for criticism the role of the Romantic poet. Indeed it is Coleridge who first used the term 'practical criticism' in his Biographia Literaria. Through 'practical criticism'-as he called his critical analysis of the works of Shakespeare-Coleridge hoped to discover the essential qualities that are symptomatic of poetic power or the imagination. ${ }^{9}$ For Coleridge, literary authority resided in the poet and, most important, the poetic process. And Shelley uttered the most grandiloquent pronouncements on this authority of the Romantic poet when he called poets the unacknowledged legislators of the world.10

For the Romantics, construing the literary as a site of withdrawal was in fact a political protest. Practical criticism replaced poetic composition as the base from which the scientific aridity and materialism of industrialised society were challenged by the human spirit and creativity. Cleanth Brooks, a major figure among the new critics, claimed that what he and I.A. Richards shared was an agreement that 'the greatest and most enduring poetry ... manifested to a high degree Coleridge's synthesizing imagination'.11 Authority in the academy is vested in the figure of the critic-teacher, however-the 'priest or rabbi of literary capital' as Jim Merod has called him-because it is criticism that has the responsibility of evaluating and promoting the transformative power of imaginative literature, and its goal is to produce a readership rather than to generate new writing. 12

'Practical criticism', according to Hugh Bredin, 'as a teaching device, means the close and attentive reading of literary texts, usually poetry, usually by a small group, under the guidance of a tutor'.13 This could easily describe the writing workshop, where criticism is applied to student manuscripts as well as literary texts. Indeed, R.P. Blackmur, whom at least one commentator has claimed was responsible for the 'invention' of New Criticism, 'earned his keep' teaching Creative Writing with Allen Tate at Princeton University's Creative Arts Program from 1940.14 D.G. Myers has even claimed that 'the method that came to be known as "practical criticism" or "close reading" was founded upon the sort of technical discussion of poetic problems that would occur among a group of poets', in particular the Fugitive group at Vanderbilt, which included many of the New Critics. ${ }^{15}$ And Cleanth Brooks suggests that his ideas on the necessity of tension and unity between individual words in the whole poem were gained from the Fugitives' poetry before I.A. Richards's Practical Criticism displayed this concept in critical commentary. 16

Yet Creative Writing, which developed alongside the New Criticism in a handful of American universities from the 1930s, was left with a denuded romantic aesthetics, adopting an expressivist theory of authorship that democratised the poetic imagination as a means of self-development, and a craft-based pedagogical practice, characterised by the term 'reading as a writer', in which the ubiquitous advice to 'show' rather than 'tell' 
operationalises the didactic heresy at the structural and syntactic level as well as the thematic level.17 It thus perpetuates the dead end of the romantic legacy known as art for art's sake. The workshop model offers no figure of the writer for students and teachers other than that of the artist dedicated to the discovery of a personal voice and the development of a craft. The university, in this formulation, is nothing but a garret in the ivory tower, and this attitude persists today.

For instance, the only mention of a social function for writers on the website for the Associated Writing Programs in America is the statement that in 'creative writing workshops ... stories and poems are made as gifts for readers and listeners', which is 'a highly civilized and humane act'. 18 In Australia to date the main function of the Australian Association of Writing Programs (established in 1996) has been to debate whether creative work can be construed as research for the purposes of funding and assessment. 19 So the representative bodies of Creative Writing across two countries see the writer as a literary Santa Claus or an academic careerist, both chasing professional success in the literary establishment. Is it any wonder that Creative Writing has not claimed a position of literary authority in the New Humanities if it cannot elaborate a more forceful figure of the writer?

\section{- Oppositional CRITICISM}

According to Leela Gandhi, the New Humanities are characterised by 'oppositional and anti-humanist criticism'.20 The term 'oppositional criticism' derives from Edward Said's 1983 book, The World, the Text, and the Critic: 'Were I to use one word consistently along with criticism (not as a modification but as an emphatic) it would be oppositional'.21 Oppositional criticism is founded on the assumption that the concept of autonomous aesthetic value expounded by practical criticism, rather than being a spiritual salve against a materialistic capitalist society, is in fact one of its chief ideological buttresses. The new function of criticism, characterised by Terry Eagleton as a 'struggle against the bourgeois state', breaks with the tradition of evaluation, preferring to uncover the invisible political work that criticism does in the realm of culture by relating literary works to the social forces of cultural production and consumption, or by undermining their metaphysical assumptions. ${ }^{22}$ And it sees this textual critique as the base for social change, rather than cultural defence.

The figure of the critic, then, no longer traces its lineage to John Dryden, the 'father of English criticism', or to the Arnoldian tradition of cultural heritage, but to the tradition of the intellectual with a political responsibility, and in particular the Marxist intellectual. 23 The typical model for the oppositional critic has been that of Foucault's 'specific intellectual'. 24 This is exemplified by Frank Lentricchia's Criticism and Social 
Change (1983), where he asks 'Can a literary intellectual, to come to the issue that most preoccupies me, do radical work as a literary intellectual?'25 For Lentricchia and many others throughout the 1980s, such as Jim Merod, Terry Eagleton, Paul Bove and Tony Bennett, a literary intellectual was defined as a critic and university teacher of English, whose specific role was to challenge the aesthetic view of literature and, in Lentricchia's words, 'instigate a culturally suspicious, trouble-making readership'. 26

In this formulation there is no complementary vision of the writer, within or without the university, for literature is placed in an antagonistic relationship with criticism, and the writer in the outdated mode of the universal intellectual. 'To this day', David Galef claimed in 2000, 'a tacit war exists between literary critics and writers, though both usually publish and teach within the same department'.27 Some years earlier Marjorie Perloff had described this relationship as a battle between the A Team of the Creative Writing Workshop and the B Team of the Graduate Seminar in Theory. 28 This division may not seem so striking in Australia, but when Robert White reviewed 'The State of English Studies in the 1990s', he was able to describe the relationship between theory and Creative Writing in these terms:

It was, by and large, literary theorists who helped to 'open the box' of English Studies, prising the way for creative writing as a respectable research pursuit. And yet the creative writers, generally speaking (and with some notable exceptions) are the ones within our English departments who are most suspicious of theory. After all, what author would want to embrace a movement that made its reputation by killing off the author? 29

I would like to briefly consider one attempt to negotiate this division, provided by the Englishman Robert Miles, because it is based on the same observation made by White and has been endorsed by at least one Australian commentary as an 'ingenious model' of Creative Writing pedagogy.30 'I believe', Miles wrote in 1992, 'that at bottom there is an irreducible tension between the manoeuvres of contemporary theory and the practice of teaching writing'. ${ }^{31}$ He argues, however, that this can be a productive tension in the workshop, because it 'affords the student the opportunity of comparing theories of how texts come into being with the actual experience of bringing texts into being. 32

For Miles, 'contemporary theory' is exemplified by poststructuralist critiques of authorship. But poststructuralism does not provide a theory of how texts come into being, or an impersonal substitute for individual experience of the creative process. It provides a theory of the production of textual meaning, based in a linguistic unconscious. In which case, to pit empirical practice against theoretical speculation in the writing workshop only provides a domestication of the insights of theory. It leads Miles to claim that Barthes's theory of the author entering his own death at the moment 
of writing enables students to understand how writers assume a narrative persona or enter the voice of their characters, and that, in turn, discussion of craft, as a series of technical decisions, recentres the subject, supposedly questioning theory. Too many writers see the death of the author as the apotheosis and end point of theory, as if it had never moved on from Barthes's 1960s polemic, and seem to believe that their living existence somehow disproves his thesis.

The tension between theory and practice, Miles suggests, is also 'the conflict between regarding writing from the point of view of the professional writer' and 'regarding texts from the vantage point of literary criticism', or between a verbal arts degree and a literary studies degree. 33 Miles argues for Creative Writing as a verbal art injected into literary studies, which means less emphasis on the student as an aspiring writer and more on the student as a critic. This does little to help the majority of writing programmes taught in the former mode, which is typical of attempts to construct 'integrated' programmes of creative writing and literary criticism. 34

The use of Theory in Creative Writing also operates as a reconfigured aesthetics by proposing ideal models of writing. The teaching of fictocriticism, for instance, flourishes in the wake of the post-structuralist collapse of generic boundaries between literature and criticism and the challenges of feminist theory to academic discourse. 35 Yet poststructuralist theory deriving from the work of Barthes and Derrida (regularly cited as influences on fictocriticism) has been castigated for its introspective self-reflexivity and political quietude. Deconstruction has been called the 'new new criticism' because its literary appropriation by the Yale school in America enabled critics to continue their hermetic interest in texts without considering the Foucauldian strain of poststructuralism. As Edward Said points out, 'Derrida's criticism moves us into the text, Foucault's in and out'. 36

If, like the New Humanities, Creative Writing is to go beyond Theory, it must also get outside the text and explore how literature operates in society, not, in Foucault's words, as a substitute or 'general envelope for all other discourses', but as an active social agent alongside other discourses. ${ }^{37}$ Creative Writing must become more than a pre-professional training ground for artists dedicated to their craft and to a personal vision of the world created by their imagination and realised through their individual voice or style, and for whom theory is an antagonistic discourse. Equally, the writing workshop needs to be more than a haven for avant-garde experimentalism where Theory provides a liberation from outmoded generic distinctions. Rather, a new vision of authorship needs to be elaborated, where literature is an intellectual practice alongside other non-literary discourses in the academy, and where the division between fiction and non-fiction still exists, but in a non-hierarchical relationship. 
I suggest that the distinction between the practice of artists and the theory of critics can be circumnavigated by collapsing both figures into that of the intellectual, a figure that incorporates both, without the need for hybridity, because it is based on a vision of social agency rather than a theory of generic form or of the creative process. For an artist to be an intellectual it is less important to have a theory of writing than to possess a vision of how a literary work might operate in society and to assume responsibility for it.

\section{— Writers and the KNOWLedge Class}

My interest in the intellectual is not as the central figure for a revolutionary politics or a struggle within and against 'regimes of truth', but as the focus for an understanding of the institutional conditions in which all writing takes place. A central preoccupation of Cultural Studies since the inception of the Birmingham school has been the figure of the intellectual. The most exhaustive examination (and example) of this preoccupation is John Frow's Cultural Studies and Cultural Value (1996). In this book Frow draws upon the work of writers such as Alvin Gouldner, Barbara and John Ehrenreich, and Pierre Bourdieu to situate 'cultural intellectuals' within a broader professional-managerial or knowledge class.

Intellectuals are defined as professionals in possession of cultural capital, or stored mental labour, which provides them with economic gain. For their reproduction they rely on a system of credentialising through education, rather than non-meritocratic authority in the form of privilege, money or state power. Frow argues that academics or 'cultural intellectuals' are a 'local fraction' of this knowledge class, with a 'commitment to the institutions of cultural capital, and simultaneously a set of anxieties about [their] place within these institutions'.38

If one wished to locate Creative Writing within this framework, the awarding of degrees in writing can be seen as an attempt to absorb the 'placeless' writer into the institutional apparatus of the knowledge class by imposing systems of professional training and accreditation on the practice of writing. This argument has often been levelled against writing programmes. A.D. Hope, for instance, claimed in 1965, after a visit to America, that universities were breeding their own supply of literature and soon there would be no more wild writers left. 39 Such alarmist critiques, however, tend to neglect consideration of literature as an institutionalised profession.

One does not become a writer simply by virtue of putting pen to paper, or fingertip to keyboard. One is credentialled as a writer by virtue of acquiring agents, securing publishing contracts, being reviewed, selling books, and winning prizes and grants, as well as gaining membership in professional organisations such as the Australian Society of Authors. Writers are members of a new class of intellectuals because they control their 
domain of knowledge (literature), but do not own the means of production (the publishing industry), and they are distinguished from unskilled wage earners by their possession of cultural capital-in this case, their talent and professional writing skills. The aesthetic, or literary value, is thus an economic commodity.

It is obvious that Creative Writing is one institutional site of the literary establishment, for it does provide employment for writers as writers, and skills training for aspirants. It does not, however, perform a necessary function in the reproduction of literature. Teachers of Creative Writing do not need university positions to write (although they may need the income to support their writing) and students do not become qualified writers by virtue of their study. In which case, Creative Writing must have another function beyond its 'official' purpose of employing and training writers; it must have a function specific to the university.

The university is a site for the reproduction of a broad intellectual or professionalmanagerial class via professional training and accreditation. In other words, the university is not where the knowledge class operates, but where it trains and recruits. Humanist academics, or those cultural intellectuals who are trained and accredited to stay within the university, are members of a broader class of knowledge workers, but their professional domain of knowledge remains largely within its main apparatus of reproduction. So if Creative Writing is a site for the professional training of writers, but is not a necessary system of accreditation, its main function is to contribute to the domain of knowledge of cultural intellectuals within the academy by the provision of a literary education. The performance of this necessary function in fact contributes to the goal of reproducing literature as a profession through the employment and training of writers, precisely because the domain of knowledge that incorporates Creative Writing takes literature as its object of study. This knowledge sustains the profession of literature by affording it cultural prestige - thus increasing its capital or potential to generate more capital, not to mention the direct sales generated by reading lists.

In order to reconcile its professed but not accredited purpose of training writers with its necessary function as a contribution to academic teaching and research, Creative Writing, however, must elaborate a figure of the writer capable of straddling these two domains. The model of the writer as a professional artist for whom the university is only a place for the transmission of craft skills and a knowledge of literary models lacks the symbolic force to perform this reconciliation between unaccredited purpose and necessary function. I will argue that it is the pseudo-mythic model of the public intellectual who can straddle the academic world and the public sphere, and has become the exemplary figure of the New Humanities, which provides the way forward for Creative Writing. 


\section{- The public intellectual}

The current preoccupation with the idea of the public intellectual seems to have been prompted by Russel Jacoby's The Last Intellectuals: American Culture in the Age of Academe (1987). In this book Jacoby claimed that preoccupation with intellectuals as a sociological class was symptomatic of a decline in public intellectual life and the dearth of independent intellectuals, or 'writers and thinkers who address a general and educated audience'. 40 Since the publication of Jacoby's book the idea of a public intellectual has engaged critical interest throughout the 1990s, becoming the subject of several symposia and conferences, and seeping into our general lexicon. ${ }^{41}$ That the function of criticism has become absorbed in this wider concern with the social role of the intellectual is evidenced by Edward Said's 1993 Reith Lectures, published as Representations of the Intellectuals. In The World, the Text and the Critic, Said spoke of the 'critical consciousness' being embodied in the oppositional critic and called for a more 'worldly' textual criticism. Ten years later he had shifted from a vision of criticism within the university to a vision of the intellectual outside the university. He speaks of the need for intellectuals to operate as independent 'amateurs', rather than institutionalised professionals, and to 'speak the truth to power'. 42

Debate about the figure of the public intellectual and what it represents is generally organised around the terms established by Jacoby's book: that intellectual work now takes place largely within the academy. Those who agree with Jacoby are concerned with how academics can overcome their professional myopia and engage with the general public by moving between academia and the world of journalism, either to overcome the obscurantist jargon of Theory, or to disseminate the insights of Theory more broadly. Those who disagree challenge his outmoded concept of the public sphere and argue that as teachers in public institutions, as researchers who publish their work, and as professional media consultants, academics already operate as public intellectuals. Or they point out that academics cannot simply choose to become public intellectuals; this depends on the workings of the media. 43

What has given the figure of the public intellectual its current cachet, however, is the fact that jeremiads against its disappearance, attempts to revive it, and defences of academic work all overlap with moves to reconfigure the humanities as an institution with greater public influence. One recommendation of the 1998 review of the humanities, Knowing Ourselves and Others, was that 'Universities further facilitate and provide incentives for the contributions that academics make to the public discussion of issues of importance' and 'extend the connections between Humanities scholars and the media'. ${ }^{4}$ 
Bob Hodge wrote in 1995 that the 'values which people working in cultural studies and the New Humanities sincerely and strongly hold are labelled as political correctness'. 45 Anti-political correctness campaigns flooded the American media in the early 1990s and forced humanities departments to defend their activities publicly, while privately questioning them. In the introduction to an anthology of essays entitled After Political Correctness, the editors claimed that the book was designed to develop prospects 'for a more public humanities' by 'redesigning and expanding the social and cultural role of the academic humanities'. 46 It is due to both the conservative critique within the media of the dangers of political correctness, and the disillusionment with dehistoricised Theory of left-leaning intellectuals within the academy, that the idea of the public intellectual gains purchase throughout the 1990s.

In Australia complaints about political correctness gained a much broader social context with the election of a conservative federal government in 1996. The term was levelled against so-called cultural 'elites', characterised as left-wing apologists for minority interest groups. This coincided with savage funding cuts to university budgets. So the need for humanities departments to identify ways in which they are relevant to society also arose in the face of a growing managerial culture in universities, evident in Australia in the decade or so from the Dawkins reforms to the 1999 white paper on research and research training by David Kemp, which emphasised accountability to public funds and encouraged a culture of entrepreneurialism. ${ }^{47}$

These social and institutional pressures overlap with the goals of Cultural Studies itself, an interdisciplinary enterprise concerned with producing politically engaged critiques of the everyday and the power relationships involved in culture as a whole way of life. This overlap is most evident in the development of that section of Cultural Studies known as Cultural Policy, which, according to Tony Bennett, was both a practical response to the Dawkins reforms and a theoretical reformulation of cultural theory and critical practice along Foucauldian lines. 48

\section{- Creative writing And public intellectuals}

The public intellectual has become the exemplary figure of the New Humanities, not necessarily as a model which individual academics can aspire to and train students to take up, but as a zone of contestation, a discursive site in which debates about the institutional function of the humanities in the wider community are played out. There is no specific figure of literary authority in the New Humanities, no critic to proclaim upon literature as a distinct realm. Rather, there is a more free-ranging figure of the intellectual whose work is motivated by oppositional criticism in its broadest sense, that is, textual 
or cultural critique of received opinion, with the ultimate aim of effecting social change, or at least alteration of public opinion, beyond the refinements of disciplinary knowledge. If Creative Writing is able to elaborate a figure of the writer as a literary intellectual in this sense, it will claim a stronger disciplinary position within the New Humanities than it will by perpetuating a theory/practice divide or evading it with hybrid forms of writing. The narrative of generic supersession implied by a category such as fictocriticism, which nonetheless relies for its dynamism on a continued separation between creative and critical genres, does not help address the issue of how purportedly 'naïve' works of literature, such as realist novels or confessional poems, operate in contemporary society or critical practice. Nor does it help provide strategies for the writing workshop to discuss and teach these far more popular forms of literature.

One of the main problems seen to be facing attempts by academics to operate as public intellectuals is the Research Quantum, which will award points to refereed journal articles, but not to articles in mass-circulation newspapers or magazines. This is also the problem that faces teachers of Creative Writing. Those who teach in Creative Writing are hired not only because of their academic records, but because of their publishing record outside the academy. In this case, teachers of writing wish to claim research points for their 'public' writing.

The traditional $\mathrm{PhD}$ is a rite of passage for young intellectuals seeking academic work, but its emphasis on what Judith Brett calls 'the endless qualification', and the necessity for specialisation rather than overarching commentary, means that it is designed for examiners rather than a general, even a general academic readership. ${ }^{49}$ Creative Writing is somewhat different. Those who undertake postgraduate work in this discipline are more likely to be seeking a general audience rather than an academic one, because their medium is not academic prose, but fictional or poetic writing. But if writers address a public, they are not considered as intellectuals, or at least, not in the form with which they make this address.

If the forum of the public intellectual is the media, the form is non-fiction-reviews, essays, newspaper columns, public lectures, panel sessions, television and radio interviews. A writer of novels and stage or screenplays, and less commonly of poetry, can command a presence as a public intellectual, but only by stepping outside the realms of fiction and operating in the forms mentioned above. That is, writers' fictional work may get them noticed in the public sphere, but they can only operate and be acknowledged as public intellectuals if they write columns, give lectures or provide interviews. For instance McKenzie Wark has claimed that 'If there is one little window through which younger people get into traditional zones of public life at the moment it is creative writing'. 50 
Here he is thinking specifically of writers of grunge fiction and the possibilities of a 'young public' being formed around them. These writers were popular at writers' festivals, Wark claims, when 'grunge' was a marketable category, but 'I'm still waiting for the gatekeepers to give them a go as broadcasters on ABC Radio National, or as columnists in the newspapers, or to feature at conferences organised by bodies like the National Book Council'.51 In making this point, Wark demonstrates that it is the media 'vector' of fiction, alongside the Internet and womens magazines, which he points out as unacknowledged public forums of debate, that militates against these writers as much as their youth. In an interview with Robert Dessaix, Don Anderson has claimed 'I don't think that literary intellectuals_or let's say literary practitioners such as poets, novelists or dramatists_ought to have more attention paid to them when they speak about larger issues of state than anybody else with an informed vote'.52

To encourage a view of literary practice as preparatory work for the role of public social commentary in more authoritative forms of discourse is not a viable option for the discipline of Creative Writing, as this neglects a consideration of the work writers do as writers. Of course, some writing courses teach fiction and poetry alongside journalistic and professional writing, and many writers function as reviewers and journalists to supplement their income, but I am interested in retaining the integrity of Creative Writing as a discipline of intellectual work rather than denying that writers can perform in other modes of public discourse.

It is, of course, notoriously difficult to define exactly what literature is: is it nonfiction; figurative language; writing which employs 'literary' techniques such as narrative, character, etc.; writing which evokes emotional rather than intellectual responses; writing which is creative or imaginative? It is relatively easy, however, to accept what sort of writing operates as literature. Literature is what fiction or poetry editors accept for publication, what gets shelved in those sections in bookshops, what is reviewed in those categories in newspapers and magazines, what wins literary prizes and grants. Literature is what people read when they want to be entertained, or to escape into a fictional world, or to appreciate the heightened uses of language. Literature is what thousands of students across Australia want to write when they enrol in Creative Writing courses. So while literature may be just another form of cultural production, and cannot be defended as a special type of language, it is nonetheless the assumption of aesthetic difference that governs its operation in society. 'The ontological groundlessness of literature', John Guillory reminds us, 'in no way diminishes its social effects as a means of marking the status of certain texts and genres'.53 In which case, to treat it simply as another type of writing, as a form of rhetoric to be mastered alongside advertising and journalistic copy, may help overcome unproductive preconceptions held by some students, such as that of 
untrammelled inspiration, but it nonetheless glosses over the specificity and complexity of the functions of literature.

In conceiving of a public to be addressed through the media, public intellectuals imagine a citizenry to be influenced by argument, especially about current and particular social issues. 'Creative' writers, in seeking publication, obviously seek a readership, but the audience they imagine is an abstract construct. Literature does influence the public, however, which is why some literary works are used to educate citizens and some are censored or banned for the ostensible good of the populace. The responsibility of writers lies not in whom they address or speak for, but in recognising how literature functions in society. How might this responsibility be encouraged?

For a start, as well as professional artists who pass on their knowledge to literary aspirants, university teachers of writing must be recognised as academics who practise criticism in the workshop. The question is, what sort of criticism should this be? A 'more practical institution' of practical criticism, as Robert Miles suggests, or a socially conscious oppositional criticism?54

\section{- Notes for a New PedAgogy}

In his preface to Dramatic Technique (1919), George Pierce Baker, an early teacher of play-writing, claimed 'Complete freedom of choice in subject and complete freedom in treatment so that the individuality of the artist may have its best expression are indispensable in the development of great art' and that creative courses should provide students with 'technique based on study of successful dramatists'.55 This model for teaching Creative Writing is based on the assumption that talent can't be taught, but can be nurtured by a training in literary craft. This may seem reasonable enough, but its persistence today indicates an unwillingness to engage with contemporary critiques of the aesthetic, or to extend the critical range of the workshop.

If Creative Writing is to negotiate a position within the New Humanities, perhaps the idea of complete artistic freedom for individual expression needs to be challenged. It is not viable, of course, to prescribe the content of students' writing, but it is possible to provide a critical context for its reception, beyond consideration of the quality of metaphors or the number of adjectives in a sentence or the rhythmic timing of line breaks. Is it enough for students to write stories of obviously unreconstructed sexism in the name of personal expression or artistic exploration when theoretically untenable prejudices will not be accepted in essays for other classes? Granted, problems such as these may be profitably addressed and challenged within the workshop, most likely by peers, but I'm not talking of shifting from practical considerations of craft to general discussion where the manuscript — and, by extension, its author-is put on trial for 
sexism, or readers imagine themselves in the moral situations of the characters, or even suggest that the work fails aesthetically because of a lack of thematic complexity. I am talking about employing oppositional criticism precisely to interrogate the assumptions about literature underpinning these responses and then to consider how the work in question differs from and interrelates with a range of non-literary discourses of gendered power relations.

The problem with eschewing any form of programmatic provision for this, in favour of the general dynamic of workshop discussion, is that a well-written and politically inoffensive piece will most likely pass through the aesthetic filter of the workshop process without a consideration of how it relates to anything beyond the writer's own personal satisfaction. This is buttressed by the fact that exemplary texts are generally studied for their formal qualities rather than their social or political resonances.

While formalist analysis of texts is the necessary first step in the workshop, it is unproductive for texts to be considered in an aesthetic vacuum. For instance, why have the stories of Raymond Carver been the exemplary model for so many teachers of Creative Writing? Is it because the pared-down minimalist style he represents is the most amenable to being taught, that it shores up the easy workshop practice of raking through manuscripts in search of unnecessary adjectives, embodied in the dictum of 'show don't tell'? Is it because the 'dirty realist' emphasis on the local and the mundane also helps promote the orthodoxy that aspiring writers should write from what they know?

If, for example, the work of Anne Sexton is to be studied as a model for students who wish to write of their own experiences, discussion could entail not just her use of free verse or her ability to distill autobiographical detail into poetic form, but the historical and critical context of confessional poetry, its relationship to feminist politics and psychoanalysis, its association with psychic stress and insanity, and hence its concept of writing as therapy, its shift away from 'impersonal' modernist symbolism. This would provide students not just with a range of ahistorical devices and forms, but an awareness of the political effects of aesthetic decisions.

Another strategy may be to introduce critical or theoretical works from a Cultural Studies perspective which actively interrogate the category of 'literature' in relation to things such as popular cultural practices, the media and new technologies, identity politics, policy formation and public debate. McKenzie Wark's The Virtual Republic (1997) is one possible example, for its analysis of the Demidenko affair occupies a space in a broader discussion of the culture wars in contemporary Australian society. However, intervention by teachers in the actual workshopping process may have greater pedagogical force than a more varied reading list. If each student manuscript is not only afforded a remedial technical overhauling in the workshop, but is placed within a 
broader cultural or political context by the critical expertise of the teacher, then student writers will be given a greater understanding of how their creative work might relate to their essays in other classes, and of how they might consider placing themselves as writers in society, as intellectuals who can potentially contribute to public debate via the medium of literature, rather than merely seeing potential publication as affirmation of their 'talent'.

Furthermore, it would be worthwhile for students to consider literary works from countries where social unrest or political censorship force a greater sense of responsibility upon writers to view themselves as intellectuals (especially those writers supported by International PEN). How does this social responsibility impact upon aesthetic decisions?56 While in a country such as France there is a tradition of accepting writers as intellectuals, one problem with literary culture in Australia is that it tends to be absorbed in its institutional function as an entertainment industry. As a result most publishers are increasingly unwilling to take the financial risk of publishing first-time authors whose work is deemed 'experimental'. In a 1999 interview, Jane Palfreyman, publisher at Random House, claimed that ten years ago work from Creative Writing courses 'seemed to be leaning towards the impenetrable, literary style, or a post-modernistic mish-mash of styles. Now I am receiving MA theses which include detective fiction and popular fiction - the idea of what is acceptable creative writing seems to have broadened'. 57 How are writing programmes to position themselves in relation to these conditions?

In a sense, the 'exegesis', or accompanying critical essay, which is a requirement for most research higher degrees in writing in Australian universities, fulfils the contextualising function that I have argued is necessary in undergraduate workshops. However, most teachers and students of writing are wary about this exegesis as a theoretical explanation or justification of the creative work. 58 While this contextualising work may be desirable and necessary, it need not be formally articulated and presented for submission as a critical supplement to the creative work. An alternative option might be a series of internally assessable pieces, such as book reviewing, analysis of literary media controversies, research into the history and operations of institutions such as publishing companies and funding bodies, all of which can be justified professionally whether graduates go on to become teachers or writers, and give students a broader intellectual context for their work. In other words, the grooming of students for professional involvement in the literary establishment can be complemented with a cultural analysis of the power relations implicit in its machinations. This is the model adopted by Communication and Cultural Studies.

Creative Writing hovers between a vocational traineeship for the publishing industry and an artistic haven from the pressures of commercialism. The university, however, 
cannot be seen as a neutral site where these negotiations take place. In the paradigm of the New Humanities, the university is a public institution which fosters a dialogue between academic analysis, social discourse and public policy. Creative Writing is an academic discipline which can contribute to this dialogue, but a more socially engaged and intellectually aware pedagogy needs to be articulated through a sustained theoretical encounter with the contemporary humanities. It is not by reasserting authorial intention as the basis of critical evaluation that writers will claim intellectual authority within the academy, but by exploring the political and discursive effects of their literary products and accepting responsibility for them. By doing this writers can be seen as public intellectuals, not in the nostalgic sense of independent freelance thinkers, but as participants in the intellectual work of the New Humanities.

PAUL DAWSON has a Master of Arts in Creative Writing from the University of Queensland, and recently completed a PhD at the University of Melbourne entitled 'Building a Garret in the Ivory Tower: English Studies and the Discipline of Creative Writing'. He currently lectures in the School of English at the University of New South Wales.

1. I am capitalising the phrase Creative Writing in order to distinguish it as an academic discipline, rather than the description of a practice, or a synonym for literature.

2. Ian Donaldson, 'Defining and Defending the Humanities', in A.M Gibbs (ed.), The Relevance of the Humanities, Australian Academy of the Humanities, Canberra, 1989, p. 31.

3. K.K. Ruthven, 'Introduction', in K.K. Ruthven (ed.), Beyond the Disciplines: The New Humanities, Australian Academy of the Humanities, Canberra, 1992, p. viii.

4. Jonathan Culler, Literary Theory: A Very Short Introduction, Oxford University Press, Oxford, 1997, p. 43.

5. Meaghan Morris and Stephen Muecke, 'Editorial Statement', The UTS Review, vol. 2, no. 1, 1996, p. 1.

6. For an account of the institutional development of Creative Writing see Paul Dawson, 'Creative Writing in Australia: The Emergence of a Discipline', TEXT, vol. 5, no. 1, 2001. <http:// www.gu.edu.au/school/art/text/april01/ dawson.htm>

7. See Matthew Arnold, 'The Function of Criticism at the Present Time', and 'Culture and Anarchy: An Essay in Political and Social Criticism', Culture and
Anarchy and Other Writings, ed. Stefan Collini, Cambridge University Press, Cambridge, 1993, pp. 26-51, pp. 55-187.

8. See I.A. Richards, Practical Criticism: A Study of Literary Judgment, Routledge and Kegan Paul, London, 1964; T.S. Eliot, 'Tradition and the Individual Talent', The Sacred Wood: Essays on Poetry and Criticism, Methuen, London, 1960, pp. 47-59; F.R. Leavis, Education and the University: A Sketch for an 'English School', 2nd ed., Chatto \& Windus, London, 1948; Gerald Graff, 'What Was New Criticism?', Literature Against Itself: Literary Ideas in Modern Society, Chicago University Press, Chicago, 1979, pp. 129-49; John Docker, In a Critical Condition: Reading Australian Literature, Penguin, Ringwood, 1984.

9. Samuel Taylor Coleridge, Biographia Literaria: Or, Biographical Sketches of My Literary Life and Opinions, ed. George Watson, J.M. Dent and Sons, London, 1956, p. 175.

10. Percy Bysshe Shelley, 'A Defence of Poetry', in Daniel G. Hoffman and Samuel Hynes (eds), English Literary Criticism: Romantic and Victorian, Appleton-Century-Crofts, New York, 1963, p. 190.

11. Cleanth Brooks, 'The Critics Who Made Us: I.A. Richards and Practical Criticism', The Sewanee Review, vol. 89, no. 4, 1981, p. 590. 
12. Jim Merod, The Political Responsibility of the Critic, Cornell University Press, Ithaca, 1987, p. 1.

13. Hugh Bredin, 'I.A. Richards and The Philosophy of Practical Criticism', Philosophy and Literature, vol. 10, no. 8, 1986, p. 27

14. Russell Fraser, 'R.P. Blackmur at Princeton', The Sewanee Review, vol. 89, no. 4, 1981, pp. 540, 542

15. D.G. Myers, The Elephants Teach: Creative Writing Since 1880, Prentice Hall, New Jersey, 1996, p. 131.

16. Brooks, p. 589.

17. The term 'reading as a writer' was coined by Dorothea Brande in her 1934 book Becoming a Writer, Papermac, London, 1983, pp. 99-104. However, it was R.V. Cassill's Writing Fiction, Permabook, New York, 1963, pp. 3-13, which gave the term its distinct reference as a pedagogy and reading practice which deliberately marked itself off from 'criticism'. To read as a writer is to uncover the evidence of a writer's craft in the construction of a literary work, surmising about the practical choices made from a range of possible alternatives.

18. David Fenza, 'A Brief History of AWP', AWP: The Associated Writing Programs, <http://awpwriter.org/ history.htm>

19. This debate can be followed in the pages of TEXT, the journal of the AAWP. See Paul Dawson, 'Writing Programmes in Australian Universities: Creative Art or Literary Research?' TEXT, vol. 3, no. 1, 1999, <http://www.gu.edu.au/school/art/ text/april99/dawson.htm>

20. Leela Gandhi, Postcolonial Theory: A Critical Introduction, Allen \& Unwin, Sydney, 1998, p. 52.

21. Edward Said, The World, the Text, and the Critic, Harvard University Press, Cambridge, 1983, p. 29.

22. Terry Eagleton, The Function of Criticism: From The Spectator to Post-Structuralism, Verso, London, 1984, p. 124.

23. It was Samuel Johnson who made this pronouncement on Dryden's influence, in his Lives of the English Poets, 2 vols, Oxford University Press, London, 1952, vol. 1, p. 287.

24. See Michel Foucualt, 'Truth and Power', Power Knowledge: Selected Interviews and Other Writings 1972-1977, ed. C. Gordon, trans. Gordon and others, Pantheon, New York, 1980, pp. 109-33; Michel Foucault, 'Intellectuals and Power: A Conversation Between Michel Foucault and Gilles Deleuze', Language, Counter-Memory, Practice: Selected Essays and Interviews, ed. Donald F. Bouchard, trans. Bouchard and Sherry Simon, Cornell University Press, New York, 1977, pp. 205-17.

25. Frank Lentricchia, Criticism and Social Change, Chicago University Press, Chicago, 1983, p. 2.

26. Lentricchia, p. 11. See Merod; Eagleton; Paul Bove,
Intellectuals in Power: A Genealogy of Critical Humanism, Columbia University Press, Columbia, 1986; Tony Bennett, Outside Literature, Routlege, London, 1990.

27. David Galef, 'Words, Words, Words', in Peter C. Herman (ed.), Day Late, Dollar Short: The Next Generation and the New Academy, State University of New York Press, Albany, 2000, p. 169.

28. Marjorie Perloff, 'Homeward Ho! Silicon Valley Pushkin', American Poetry Review, no. 15, 1986, p. 45 .

29. Robert White, 'The State of English Studies in the 1990s', in Reference Group for the Australian Academy of the Humanities (eds), Knowing Ourselves and Others: The Humanities in Australia into the 21st Century, 3 vols, Commonwealth Government of Australia, Canberra, 1998, vol. 2, p. 103.

30. Jeri Kroll, 'A or C: Can We Assess Creative Work Fairly?', TEXT, vol. 1, no. 1, 1997, <http:// www.gu.edu.au/school/art/text/april97/kroll.htm>

31. Robert Miles, 'Creative Writing, Contemporary Theory and the English Curriculum', in Moira Monteith and Robert Miles (eds), Teaching Creative Writing: Theory and Practice, Open University Press, Buckingham, 1992, p. 36.

32. Miles, p. 37.

33. Miles, p. 37.

34. See for instance, Ian Reid, 'The Crisis in English Studies', English in Australia, no. 60, 1982, pp. 818.

35. For an account of the relationship between fictocriticism and Creative Writing see Anne Brewster, 'Fictocriticism: Undisciplined Writing', in 'Teaching Writing: Proceedings of the First Annual Conference of the Association of University Writing Programmes', UTS, 11-13 October 1996, pp. 29-32.

36. Said, p. 183.

37. Michel Foucault, 'The Functions of Literature', Politics, Philosophy, Culture: Interviews and Other Writings 1977-1984, ed. Lawrence D. Kritzman, trans. Alan Sheridan and others, Routledge, New York, 1990, p. 308.

38. John Frow, Cultural Studies and Cultural Value, Clarendon Press, Oxford, 1995, pp. 130-1.

39. A.D. Hope, 'Literature versus the Universities', The Cave and the Spring: Essays on Poetry, Rigby, Adelaide, 1965, pp. 164-73.

40. Russel Jacoby, The Last Intellectuals: American Culture in the Age of Academe, The Noonday Press, New York, 1987, p. 5.

41. See 'Symposium: The Professionalization of Intellectuals', University of Toronto Quarterly, no. 58, 1989, pp. 439-512; Bruce Robbins (ed.), Intellectuals: Aesthetics, Politics, Academics, University of Minnesota Press, Minneapolis, 1990; 
the special issue on public intellectuals in Meanjin, vol. 50, no. 4, 1991; 'Symposium: The Public Intellectual', Australian Book Review, no. 182, 1996, pp. 19-22; Paolo Bartoloni, Karen Lynch, and Shane Kendal (eds), Intellectuals and Publics: Essays on Cultural Theory and Practice, School of English, La Trobe University, Melbourne, 1997; Robert Dessaix (ed.), Speaking Their Minds: Intellectuals and the Public Culture in Australia, ABC Books, Sydney, 1998.

42. Edward W. Said, Representations of the Intellectual: The 1993 Reith Lectures, Vintage, London, 1994.

43. For arguments in favour of Jacoby's thesis see: Graham Good, 'Cultural Criticism or Textual Theory?', University of Toronto Quarterly, no. 58, 1989, pp. 463-9; Judith Brett, 'The Bureaucratisation of Writing: Why So Few Academics are Public Intellectuals', Meanjin, vol. 50, no. 4, 1991, pp. 513-22; Helen Daniel, 'The Public Intellectual: Mavericks and Chamelons', in Paolo Bartoloni, Karen Lynch, and Shane Kendal (eds), Intellectuals and Publics: Essays on Cultural Theory and Practice, School of English, LaTrobe University, Melborne, 1997, pp. 33-9. For arguments in favour of the public dissemination of Theory see: Michael Bérubé, Public Access: Literary Theory and American Cultural Politics, Verso, London, 1994; McKenzie Wark, 'On Public Intellectuals: Ruminations from Back Paddock', in Intellectuals and Publics, pp. 85-99. For arguments against Jacoby see: Henry A. Giroux, 'Academics as Public Intellectuals: Rethinking Classroom Politics', in Jeffrey Williams (ed.), PC Wars: Politics and Theory in the Academy, Routledge, New York, 1995, pp. 294-307; Stanley Fish, Professional Correctness: Literary Studies and Political Change, Clarendon Press, Oxford, 1995; Meaghan Morris, 'Cultural Studies', in Beyond the Disciplines: The New Humanities, pp. 1-21; Meaghan Morris and Iain McCalman, 'Public Culture', in Knowing Ourselves and Others, vol. 3, pp. 1-20. 44. Morris and McCalman, vol. 1, p. xxxvi.
45. Bob Hodge, 'Preface', in Andrew Johnson, Murray Lee, Katrina Schlunke, Felicity Sheaves (eds), Off the Sheep's Back: New Humanities, University of Western Sydney, Hawkesbury, Sydney, 1997, p. 10.

46. Christopher Newfield and Ronald Strickland (eds), After Political Correctness: The Humanities and Society in the 1990s, Westview Press, Boulder, 1995, p. 1.

47. The Hon. Dr D.A. Kemp MP, Knowledge and Innovation: A Policy Statement on Research and Research Training, Commonwealth Government of Australia, Canberra, 1999. For an analysis of these institutional changes see Simon Marginson and Mark Considine, The Enterprise University: Power, Governance and Reinvention in Australia, Cambridge UP, Cambridge, 2000.

48. See Tony Bennett, 'Useful Culture', Cultural Studies, vol. 6, no. 3, 1992, pp. 395-408; and 'Coming Out of English: A Policy Calculus for Cultural Studies', in Ruthven, pp. 33-44.

49. Brett is quoted by Robert Dessaix in Speaking Their Minds, p. 24.

50. McKenzie Wark, 'On Public Intellectuals: Ruminations from Back Paddock', in Bartoloni, Lynch and Kendal , p. 89.

51. Wark, p. 89.

52. Dessaix, p. 14

53. John Guillory, Cultural Capital: The Problem of Literary Canon Formation, Chicago UP, Chicago, 1993, p. 65.

54. Miles, p. 39.

55. George Pierce Baker, Dramatic Technique, Houghton Mifflin, Boston, 1919, p. vi.

56. A useful article here is Andre Brink, 'Writing in a State of Emergency: The Writer's Responsibility', The Australian Author, vol. 21, no. 3, 1989 , pp. 25-8.

57. Quoted in Murray Waldren, 'Sweet Word of Youth', Literary Liaisons, <http://www.ozemail.com.au/ $\sim$ waldrenm/young.html>

58. See Dawson, 'Writing Programmes in Australian Universities'. 